\title{
Gas emissions and active tectonics within the submerged section of the North Anatolian Fault zone in the Sea of Marmara
}

L. Géli ${ }^{a,}{ }^{\star}$, P. Henry ${ }^{b}$, T. Zitter ${ }^{b}$, S. Dupréa, M. Tryon $^{c}$, M.N. Çağatay ${ }^{d}$, B. Mercier de Lépinay ${ }^{e}$, X. Le Pichon ${ }^{b}$, A.M.C. Şengör ${ }^{d}$, N. Görür ${ }^{d}$, B. Natalin ${ }^{d}$, G. Uçarkuş̧ ${ }^{d}$, S. Özeren ${ }^{d}$, D. Volker ${ }^{f}$, L. Gasperini $^{g}$, P. Burnard ${ }^{h}$, S. Bourlange ${ }^{h}$ and the Marnaut Scientific Party

\footnotetext{
a Ifremer, Marine Geosciences Department, 29280, Plouzané, France

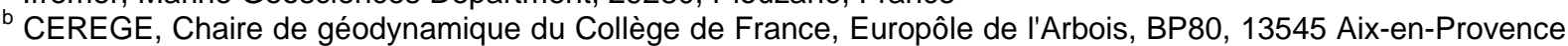
Cedex 04, France

${ }^{c}$ Scripps Institution of Oceanography, La Jolla, CA, 92093-0244, USA

d Istanbul Techical University, Istanbul Technical University, Faculty of Mines, Geology Department, Maslak, 34469 Istanbul, Turkey

${ }^{\text {e }}$ Geosciences Azur, Université de Nice-Sophia Antipolis, 250 rue Albert Einstein, 06560 Valbonne, France

${ }^{f}$ IFM-GEOMAR, Wischhofstr. 1-3, D-24148 Kiel, Germany

g ISMAR, CNR, Via Gobetti 10140129 - Bologna, Italy

h CRPG, 15 Rue Notre Dame des Pauvres, 54501 Vandoeuvre Les Nancy, France
}

*: Corresponding author : L. Géli, email address : Louis.Geli@ifremer.fr

\begin{abstract}
:
The submerged section of the North Anatolian fault within the Marmara Sea was investigated using acoustic techniques and submersible dives. Most gas emissions in the water column were found near the surface expression of known active faults. Gas emissions are unevenly distributed. The linear fault segment crossing the Central High and forming a seismic gap - as it has not ruptured since 1766, based on historical seismicity, exhibits relatively less gas emissions than the adjacent segments. In the eastern Sea of Marmara, active gas emissions are also found above a buried transtensional fault zone, which displayed micro-seismic activity after the 1999 events. Remarkably, this zone of gas emission extends westward all along the southern edge of Cinarcik basin, well beyond the zone where 1999 aftershocks were observed. The long term monitoring of gas seeps could hence be highly valuable for the understanding of the evolution of the fluid-fault coupling processes during the earthquake cycle within the Marmara Sea.
\end{abstract}

Keywords: seismicity; fluids; gas emission; Marmara Sea; North Anatolian Fault 
Associations between fluid expulsion sites on continental margins (generally called cold seeps) and active fault systems have been recognized for some time $[9,10]$. It is also known that earthquakes influence gas emissions at cold seeps, and precursor gas emissions have been observed [11]. In the Gulf of Izmit at the eastern end of the Sea of Marmara, expulsion of gas through seafloor fault ruptures was observed after the 1999 Kocaeli earthquake on the North Anatolian Fault $[12,13]$. However, detailed studies often conclude that spatial relationships between cold seeps and presumably permeable faults are complex $[14,15]$ or, worse, absent $[16]$. Other authors $[17,18]$ have suggested that it is very difficult to get free gas to pass through sediment but relatively easy to get it to go through fractures, which leads to water seeps being found in lots of places, such as outcrops of sand layers, while gas seeps more often are found associated with fractures. We here present data from acoustic surveys and Nautile submersible dives over the whole Sea of Marmara showing that, at least in some settings, distribution of gas seeps may provide indications of fault activity and even help identify buried structures. In September 2000, acoustic reflectivity images of the deeper parts of the Sea of Marmara were obtained $[19,20]$ with a $180 \mathrm{kHz}$ side scan sonar (hereafter called SAR, for "Sonar Acoustique Remorqué") towed by R/V Le Suroit, $\sim 75 \mathrm{~m}$ above seafloor (Fig. 1a). Echoes were observed before the first seafloor arrival; such echoes are known to be produced by gas 
plumes . In May-June 2007, during the MarNaut cruise of R/V L'Atalante, a SIMRAD-EK60 echo sounder operating at $38 \mathrm{kHz}$ and mounted on a fish towed at approximately $10 \mathrm{~m}$ depth was used for plume detection (Fig. 1b). Remarkably, all those sites where acoustic anomalies were detected in 2000, were still active when revisited seven years later (Fig. 2). The Sea of Marmara is also densely covered with chirp sediment sounder profiles. Fading patterns indicating the presence of gas in the sediment are systematically observed near where acoustic anomalies are found in the water column (Fig. 3). Nautile submersible dives performed at acoustic anomaly sites found manifestations of fluid outflow such as patches of reduced sediment, with 1-10 $\mathrm{m}$ size range (Fig. 4). In some of them, trains of bubbles flow out from $\sim 1 \mathrm{~cm}$ in diameter carbonate-cemented conduits. In total, bubble emissions were found at 7 of the 11 sites with water column echoes that were explored with the submersible, but some could easily have been missed by visual observation because of the small bubble sizes (1-5 mm diameter).

Most anomalies (Fig. 2) were found in the Cinarcik Basin, in the Tekirdag Basin and on the Western High. They appear less common over the northeastern Central Basin, the Central High, and are absent in the Kumburgaz Basin. A statistical approach of cold seep distribution is shown in the supplementary material. The seafloor trace of active faults is known from previous morphotectonic studies [24,25,26,27]. We analyze the relationships between gas seep distribution and active faults based on this framework, complemented on the local scale by Nautile observations.

In the Cinarcik Basin, although SAR coverage is evenly distributed over most of its surface, gas emissions are only identified along the edges of the basin. A series of acoustic anomalies were identified along the base of the northern escarpment but no bubble emission was seen with the Nautile. Cold seeps were observed on scree composed of blocks up to $1 \mathrm{~m}$ in size, near the base of a steep slope exposing cliffs of Paleozoïc rocks. Along the base of the more gentle southern slope, SAR and EK-60 surveys found acoustic anomalies within a $100^{\circ}$ striking swath of 2-3 km width and $60 \mathrm{~km}$ length. Nautile Dive 1659 on a cluster of EK-60 acoustic anomalies rising 40-150 $\mathrm{m}$ above seafloor (Fig. $3 \& 4$ ) found that the bubble emission sites within this swath are aligned along preferential orientations, controlled by fractures. One active zone striking $90^{\circ}-100^{\circ}$ could be followed for $30 \mathrm{~m}$. Another active zone, striking $130^{\circ}$, could be followed for $180 \mathrm{~m}$ along a normal fault identified as an offset on the $3.5 \mathrm{kHz}$ chirp profiles (Fig. 3). Within this active zone, individual black patches, with $1-2 \mathrm{~m}$ width and 5 to $15 \mathrm{~m}$, length were found following the same $130^{\circ}-140^{\circ}$ trend.

Between about $28^{\circ} 10^{\prime} \mathrm{E}$ and $28^{\circ} 50^{\prime} \mathrm{E}$ longitude, acoustic coverage is available mainly along the linear strike-slip transfer fault connecting the Cinarcik Basin in the east, to the Central Basin in the west. Only one, weak, 25-m high, acoustic anomaly was detected along the main fault. Instead, a cluster of gas plumes, with acoustic anomalies up to 150-m high, is documented on top of the Central Ridge at $\sim 350 \mathrm{~m}$ water depth, about $1 \mathrm{~km}$ southward of the fault. In the Central Basin, the fault scarp with the largest vertical displacement has no associated acoustic anomalies in the water column. Bubble emissions sites were detected along other fault branches, particularly at the base of the northern escarpment, and at the NE corner of the basin, close to the branching point with the main strike-slip fault. On the Western Ridge, bright acoustic anomalies were detected in the fault valley, as well as on topographic highs on either side. The strongest anomaly rises $500 \mathrm{~m}$ above the seafloor, almost reaching the sea surface (Fig. 1b). It is located on the northern side, on the top of a NE-SW anticlinal ridge striking perpendicular to the direction of compression in the Sea of Marmara shear zone [24]. 
In the Tekirdag Basin, acoustic anomalies were found along the trace of the main E-W strikeslip fault that follows the southern edge of the basin and, notably, around a known site of brackish water expulsion [26,27]. This site is located on a seafloor rupture, likely caused by an earthquake, but not dated with certainty [26,27]. Acoustic anomalies were also detected at the base of the northern escarpment (oriented $\sim 50^{\circ}$ ) of the Tekirdag Basin, corresponding to a thrust fault. Dives 1644 and 1647 at this site found vigorous bubble emissions from open fractures in the sediment and underlying bedrock (Fig. 4c).

Many, but not all, gas emission sites are located on active fault segments of the main fault zone and also in association with secondary features (Fig. 2a and 2b). This correlation may be explained if fracturing in and around fault zones provides permeable conduits for gas escape to the seafloor [29]. Coarse turbidite and mass-flow deposits may also direct fluid expulsion toward and along faults at the base of major slopes as was observed in the southeast Tekirdag basin [28]. Along the base of the northern escarpment of the Cinarçik basin, observations with Nautile further suggest that permeable scree channels the fluids laterally, at least at a shallow level. Gas seeps are also found on the axis of anticlines up to one kilometer from the main strike-slip fault trace on the Western and Central highs. Shallow extensional fractures along the anticline axis could provide high permeability conduits. Fluids expelled at these sites could either originate from within the anticline, or be channeled upward along the fault zone at depths, and diverted along permeable strata toward the crest of the anticline.

Very few gas seeps are found on the fault trace along the linear Kumburgaz fault segment connecting the Cinarcik Basin to the Central Basin and we wonder whether this feature could be related to earthquake history. Historical evidence [9] indicates that a major earthquake occurred in the central part of the Sea of Marmara in 1509. A series of earthquakes with estimated moment magnitude close to or greater than 7 occurred in 1719, 1754, and in May and August 1766 in the Sea of Marmara region, but the distribution of damage cannot resolve the exact geometry of the associated segment fault ruptures $[10,11,12]$. The next series of M>7 events comprises three earthquakes in 1894, 1912 and 1999. The 1894 earthquake affected the Cinarcik Basin and Izmit Gulf, but it is unclear which fault ruptured in the Cinarcik Basin. The 1912 earthquake ruptured the Ganos fault on land and extended some distance offshore [26], but this distance may have been quite short [10]. Whatever the interpretations, a consensus exists that the central part of the Sea of Marmara, where only a few acoustic anomalies were found, did not rupture since 1766. On the other hand, there is no definite piece of evidence for dating the last rupture of the fault segments in the Tekirdag and Central basins, where, in contrast, acoustic anomalies have been found. Hence, it is yet impossible to positively demonstrate an univocal relationship between the absence of gas escape from the main fault zone and the absence of recent rupture. Still, the Kumburgaz Basin and Central High have certainly been less affected by seismic strain or ground shaking than the Cinarcik and Tekirdag basins during the last 100-150 years. Ground shaking is known to promote gas emission after an earthquake. If the increase of sediment permeability subsequent shaking or strain persists up to about 100 years, this process could in part explain the current distribution of seeps.

In the southern Cinarcik Basin, the primary trend $\left(100^{\circ}\right)$ along which seeps are aligned corresponds to the "inner boundary fault" formerly identified in the seismic reflection sections $[13,14]$ in the westward continuation of the fault that ruptured during the August 17th, 1999 Izmit earthquake. This fault system, which displayed micro-seismic activity after the 1999 events [10,11], was still active during the winter 2005/2006 [30]. East of 28 ${ }^{\circ} 55^{\prime}$, gas escapes 
through a system of $\sim 130^{\circ}-140^{\circ}$ trending normal faults. As suggested by analog models [31], the transition from a trans-tensional shear zone at depth to en-echelon normal faults at the seafloor could be due to a change in rheology between the basement rock and the sedimentary pile. However, at the western end, the shallow structures channeling the fluid were not identified and the deeper shear zone is hypothetical. This puzzling feature may be produced in different ways. One possibility is that deep fluids migrate upward along a buried fault and escape to the sea floor distributed in a $2-4 \mathrm{~km}$ swath around the fault. Alternatively, buried slip could increase the strain rates and, thus, the permeability of the shallow sediments in a band around a deep shear zone, without need for a deep fluid source.

In conclusion, gas emission sites were successfully mapped with acoustic methods in the Sea of Marmara, and ground truthed with manned submersibles and a correlation with active faults could be established. However, the relationships between gas emissions and the seismic cycle are not understood. Our studies are preliminary though promising. They represent a first step in testing the hypothesis that there are physical and chemical changes that occur systematically with time throughout the earthquake cycle. A major goal of this work is to determine if there are signals of a precursory nature within this cycle. We currently have geochemical and hydrological observatories deployed in the Sea of Marmara at seep sites associated with tectonic features and hope to soon augment these with additional observatories, piezometers, and seismometers. Provided that correlations between strain rate and fluid and seismic activity exist and may be determined over a limited time-scale experiment, we will have defined a tool that may be used to better constrain probabilistic estimates of earthquake occurrence in the marine environment. 
Acknowledgments : We wish to acknowledge all the actors that initiated the Turkish-French collaboration and contributed to make the MarNaut cruise a reality. We also warmly acknowledge Captain and crew of $R / V$ L'Atalante and the very efficient help of the Turkish Navy to protect our ship and submersible in the zones of heavy ship traffic. Financial support from Agence Nationale de la Recherche (project ANR/ISIS) and from INSU (Project Marmarafluides) is also acknowledged. M. Tryon acknowledges NSF Award No. OCE-0647361. Discussions with Michel Bouchon were very helpful.

\section{References}

[1] Ambraseys, N. N., \& Jackson, J. A., (2000), Seismicity of the Sea of Marmara (Turkey) since 1500, Geophys. J. Int., 141, 141 (3), F1-F6. doi:10.1046/j.1365-246x.2000.00137.x

[2] Ambraseys, N., (2002), The seismic activity of the Marmara Region over the last 2000 years, Bull. Seism. Soc. Am., 92, 1-18

[3] Parson, T., (2004), Recalculated probability of $M \geq 7$ earthquakes beneath the Sea of Marmara, Turkey, $J$. Geophys. Res., 109, B05304, doi:10.1029/2003JB002667

[4] Pondard, N., Armijo, R., King, G. C. P., Meyer, B., Flerit, F., (2007), Fault interactions in the Sea of Marmara pull-apart (North Anatolian Fault): earthquake clustering and propagating earthquake sequences, Geophys. J. Int., 171, 1185-1197, doi :10 ;1111/j.1365-246X.2007.03580.x

[5] Carton, H., S. C. Singh, A. Hirn, S. Bazin, B. de Voogd, A. Vigner, A. Ricolleau, S. Cetin, N. Ocakoglu, F. Karakoc $_{\text {, }}$ and V. Sevilgen, (2007), Seismic imaging of the three-dimensional architecture of the Cinarcik Basin along the North Anatolian Fault, J. Geophys. Res, 180, B06101, doi:10.1029/2006JB004548

[6] Okay, A. I., A. Kashlar-Ozcan, C. Imren, A. Boztepe-Güney, E. Demirbag and I. Kusçu (2000), Active faults and evolving strike-slip basins in the Sea of Marmara, northwest Turkey: A multichannel seismic reflection study, Tectonophysics, 321, 189- 218

[7] Ozalabey, S., Ergin, M., Aktar, M., Tapirdamaz, C., Biçmen F., Yörük, A., (2002), The 1999 Izmit Earthquake Sequence in Turkey : Seismological and Tectonic Aspects, Bull. Seism. Soc. Am., 92, 376-386

[8] Karabulut, H., Bouin, M.-P., Bouchon, M., Dietrich, M., Cornou, C., Aktar, M., (2002), The seismicity in the Eastern Marmara Sea after the 17 August 1999 Izmit earthquake, Bull. Seismol. Soc. Am., 92, 387-393

[9] Moore, J.C., Orange, D. and Kulm, L.D. (1990), Interrelationship of Fluid Venting and Structural Evolution - Alvin Observations from the Frontal Accretionary Prism, Oregon. J. Geophys. Res., 95 (B6), 8795-8808

[10] Le Pichon et al, (1992) Fluid Venting Activity within the Eastern Nankai Trough Accretionary Wedge - a Summary of the 1989 Kaiko-Nankai Results. Earth Plan. Sci. Let., 109 (3-4), 303-318

[11] Hovland, M., Gardner, J. V., \& Judd, A. G., (2002), The significance of pockmarks to understanding fluid flow processes and geohazards, Geofluids, 2, 127-136

[12] Alpar, B., (1999), Underwater signatures of the Kocaeli earthquake of 17 August 1999 in Turkey. Turkish J. Marine Sciences, 5: 111-130

[13] Kusçu, I., Okamura, M., Matsuoka, H., Gokasan, E., Awata, Y., Tur, H. and Simsek, M., (2005), Seafloor gas seeps and sediment failures triggered by the August 17, 1999 earthquake in the Eastern part of the Gulf of Izmit, Sea of Marmara, NW Turkey. Marine Geology, 215: 193-214

[14] Henry, P., Lallemant, S.J. , Nakamura, K. , Tsunogai, U. , Mazzotti S. and Kobayashi K., (2002), Surface expression of fluid venting at the toe of the Nankai wedge and implications for flow paths, Marine Geology, 187, 119-143

[15] Gay, A., Lopez, M; Berndt, C, and Seranne M., (2007), Geological controls on focused fluid flow associated with seafloor seeps in the Lower Congo Basin, Marine Geology, 244, 68-92

[16] Paull, C. K., Schlining, B., Ussler III, W., Paduan, J. B., Caress, D., Greene, H. G., (2005), Distribution of chemosynthetic biological communities in Monterey Bay, California, Geology, 33; no. 2; 85-88; doi: 10.1130/G20927.1

[19] Rangin, C., E. Demirbag, C. Imren, A. Crusson, A. Normand, E. Le Drezen, and A. Le Bot (2001), Marine Atlas of the Sea of Marmara (Turkey), Ifremer, Plouzané, France

[20] Le Pichon, X., Sengor, A.M.C., Demirbag, E., Rangin, C., Imren, C., Armijo, R., Gorur, N., Cagatay, N., Mercier de Lépinay, B., Meyer, B., Saatcilar, R. and Tok, B., (2001), The active main Marmara fault. Earth Planet. Sci. Lett., 192: 595-616

[21] Klaucke I., Sahling H., Weinrebe W., Blinova V., Bürk D., Lursmanashvili N., Bohrmann, G., (2006), Acoustic investigation of cold seeps offshore Georgia, eastern Black Sea, Marine Geology, 231, 51-67, doi:10.1016/j.margeo.2006.05.011

[22] Merewether, R., Olsson, M.S. \& Lonsdale, P., (1985), Acoustically detected hydrocarbon plumes rising from 2-km depths in Guaymas Basin, Gulf of California, J. Geophys. Res., 90, 3075-3085. 
[23] Paull, C.K., Ussler, W., Borowski, W.S. \& Spiess, F.N., (1995), Methane-rich plumes on the Carolina continental rise; associations with gas hydrates, Geology, 23, 89-92

[24] Rangin, C., Le Pichon, X., Demirbag, E., Imren, C., (2004), Strain localization in the Sea of Marmara : propagation of the North Anatolian Fault in a now inactive pull-apart, Tectonics, 23, TC2014, doi:10.1029/2002TC001437

[25] Armijo, R., B. Meyer, S. Navarro, and G. King (2002) Slip partioning in the Sea of Marmara pull-apart : a clue to propagation processes of the North Anatolian Fault, Terra Nova, 14, 80-86.

[26] Armijo, R. et al (2005), Submarine fault scarps in the Sea of Marmara pull-apart (North Anatolian Fault): Implications for seismic hazard in Istanbul, Geochem. Geophys. Geosyst., 6, Q06009, doi:10.1029/2004GC000896

[27] Imren, C., X. Le Pichon, C. Rangin, E. Demirbag, B. Ecevitoglu, and N. Gorur, the North Anatolian Fault within the Sea of Marmara : a new interpretation based on multi-channel seismic and multi-beam bathymetry data, Earth Planet. Sci. Lett., 186, 143-158, 2001

[28] Zitter, T. A. C., Henry, P., Aloisi, G., Delaygue G., Çagatay M. N., Mercier de Lepinay, B., Al-Samir, M., Fornacciari F., Tesmer, M., Pekdeger, A., Wallman, K., and Lericolais, G., (2008), Cold seeps along the main Marmara fault in the Sea of Marmara (Turkey), Deep-Sea Research, doi:10.1016/j.dsr.2008.01.002

[29] Sorey, M. L., Grant, M. A., and Bradford, E., (1980), Nonlinear effects in two-phase flow to wells in geothermal reservoirs, Water Resources Research, 16, 767-777

[30] Bonhoff, M., Aktar, M., Bulut, F., Childs, D., Gorgün, E., Karabulut, H., Dresen, G., (2007), The North Anatolian Fault in the broader Istanbul/Marmara region : seismic monitoring of a seismic gap, EOS, Am. Geophys. Union Fall Meeting, San Franciso (Poster \& Abstract)

[31] McClay, K., \& Dooley, T., (1995), Analogue models of pull apart basins, Geology, 23, 711-714 


\section{FIGURE CAPTIONS}

Figure 1a : Example of side scan sonar (SAR) data collected in september 2000 with R/V Le Suroit, using a $180 \mathrm{kHz}$ system towed $\sim 70$ to $80 \mathrm{~m}$ above seafloor. The presence of acoustic anomalies in the water column below the SAR was only recognized recently. In the usual data processing flow of side scan sonar data, the signal recorded before the first seafloor arrival is discarded and the later signal, corresponding to seafloor backscatter, is projected on a flat surface or on topography On the raw data, however, echoes may be observed before the first seafloor arrival within a 100-200 m swath, depending on the elevation of the SAR above the seafloor. Gas plumes have for long been known to produce such echoes [19, 20,21]. The right image represents the reflectivity image that is traditionally used by marine geologists (see on the middle right a typical trace of landslide). The central white stripe below ship tracks is a « blind zone », indicating signal propagating in the water column. The left image is a blow up of the yellow box extracted from right image, showing details of the «white stripe».

Figure 1b : Example of acoustic anomalies, detected near $40^{\circ} 49^{\prime} \mathrm{N}, 2^{\circ} 47^{\prime} \mathrm{E}$ in May-June 2007, during the MarNaut cruise of R/V L'Atalante, using a SIMRAD-EK60 echo sounder (operating at $38 \mathrm{kHz}$, a standard for fishery purposes). The transducer unit was mounted on a fish towed $5 \mathrm{~m}$ off the ship and at approximately $10 \mathrm{~m}$ depth, limiting ship speed to 3 knots. The opening angle of the acoustic lobe is $7.1^{\circ}$. Average water depth is about $666 \mathrm{~m}$, corresponding to a 80-m diameter footprint on the seafloor. The horizontal scale can be inferred from the ship speed and the distance (equal to $1570 \mathrm{~m}$ ) between the two vertical lines indicating the position of the vessel at $15 \mathrm{~h} 06$ and $15 \mathrm{~h} 23$. The source of this acoustic anomaly, ground truthed during Nautile dive 1662, is not located on the fault valley, but on top of the Western Ridge, less than $1 \mathrm{~km}$ north of the fault trace.

Fig. 2 : Distribution of acoustic anomalies, superimposed on the bathymetric map ${ }^{17}$ of the deeper parts of the Marmara Sea. Active fault traces are based on previous morphotectonic studies [24 to 27]. 2a) White lines and yellow dots routes followed by R/V Le Suroit [19,20] and location of acoustic anomalies detected in september 2000 using the deep tow SAR. 2b) White lines and red dots respectively indicate routes followed by R/V L'Atalante in may-june 2007 and location of acoustic anomalies detected using the EK-60 sonar.

Figure 3: Detailed view of acoustic data coverage in the Cinarcik Basin. Red and yellow dots indicate the location of the acoustic anomalies detected with, respectively, EK-60 (track lines in red) and SAR (tracks in orange). High resolution chirp (3.5 kHz) lines exhibit fluid-related perturbations in the surface sediments that are exactly correlated to the presence of gas escapes. Insert shows an example of acoustic anomaly detected using the EK-60 which was then ground truthed with Nautile (Fig. 4a and 4b). Acoustic anomalies observed in the southern part of the Cinarcik Basin appear to be related to the faulting system documented by the densily spaced seismic data collected in 2001 during the Seismarmara Cruise [Carton et al, 2007]. The thick dotted, brown line indicates the trace of the «inner boundary fault» identified in seismic reflection data [5,6] (this fault named fs2 in [Ref. 5]). Small blue dots indicate the location of aftershocks [8] recorded from August 27 ${ }^{\text {th }}, 1999$ to September, $16^{\text {th }}$, 1999.

Figure 4 : Examples of bubble escapes ground truthed with submersible Nautile during the MarNaut cruise. 4a) Black patch in South Cinarcik Basin near 40 43’ N ; 29 ${ }^{\circ} 7^{\prime} \mathrm{E}, \sim 1200 \mathrm{~m}$ 
water depth, during Dive 1659. Trains of bubbles were found degassing out from small (1 to 2 $\mathrm{cm}$ in diameter) chimney conduits within these black patches; 4b) Acoustic anomalies were also detected at the base of the northern escarpment (oriented $\sim 50^{\circ}$ ) of the Tekirdag Basin. Gas bubbles were found during Dive 1644 to escape from tensile cracks in the bedrock, striking in the northwestern direction $\left(320-330^{\circ}\right)$ and connected by elongated, continuous strips of black sediment. 

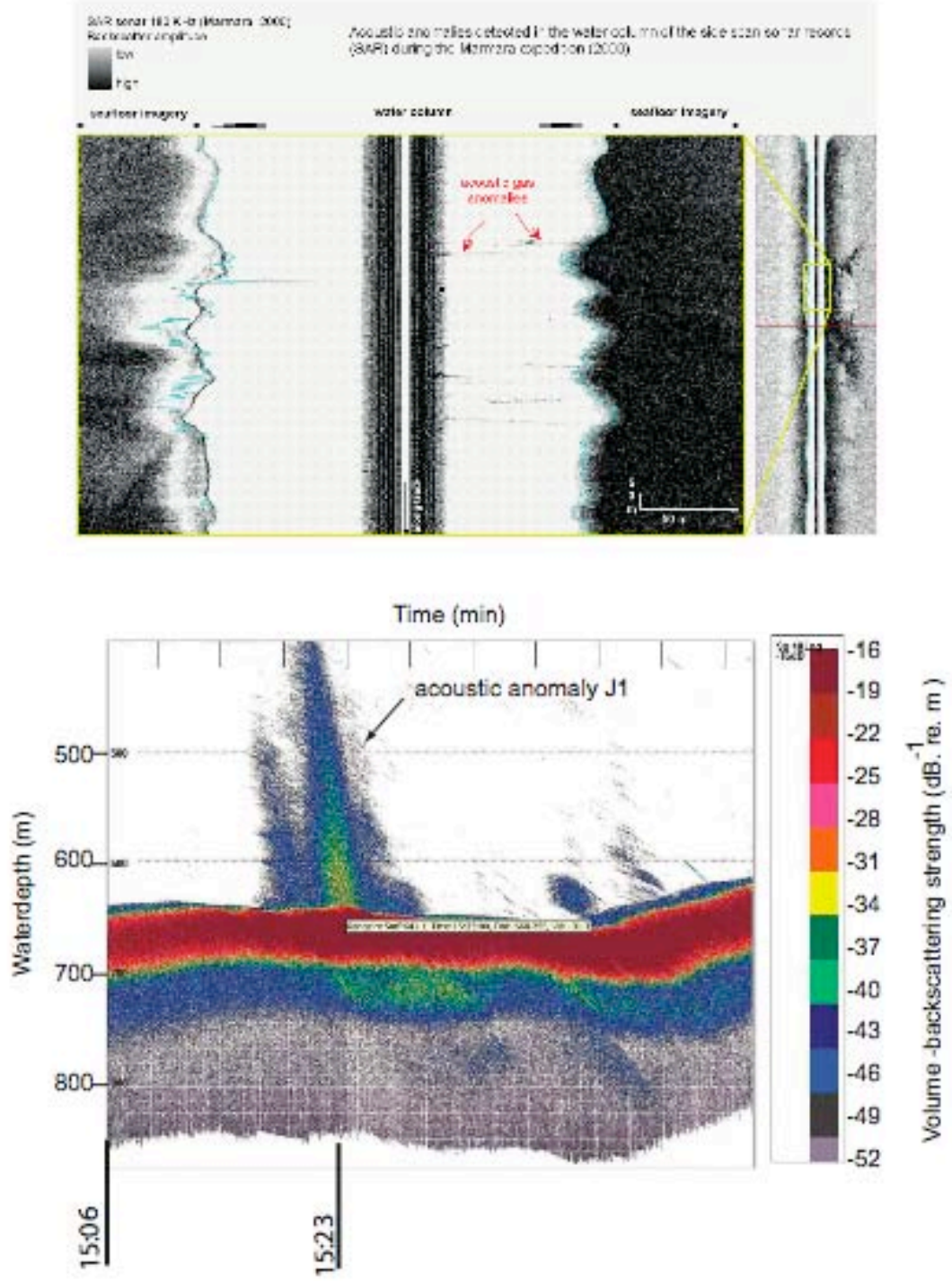

FIGURE 1 


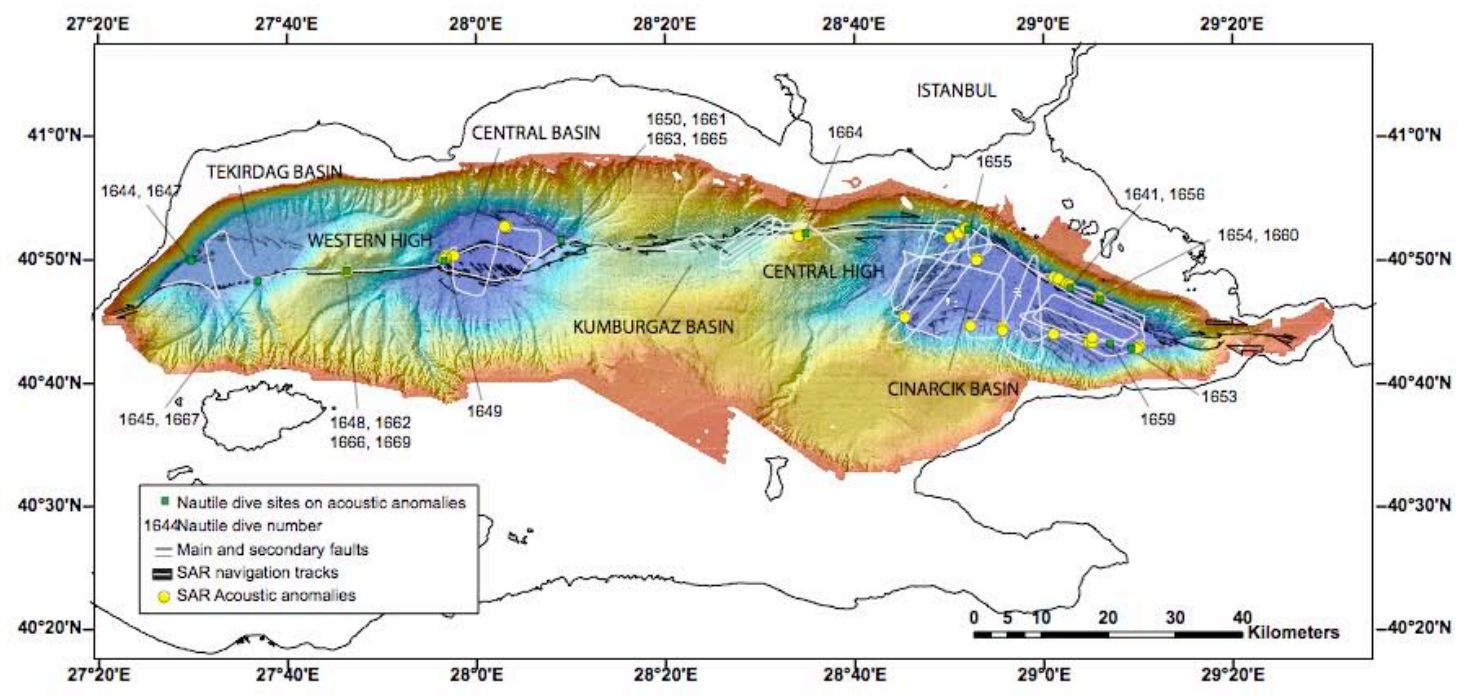

FIGURE 2a

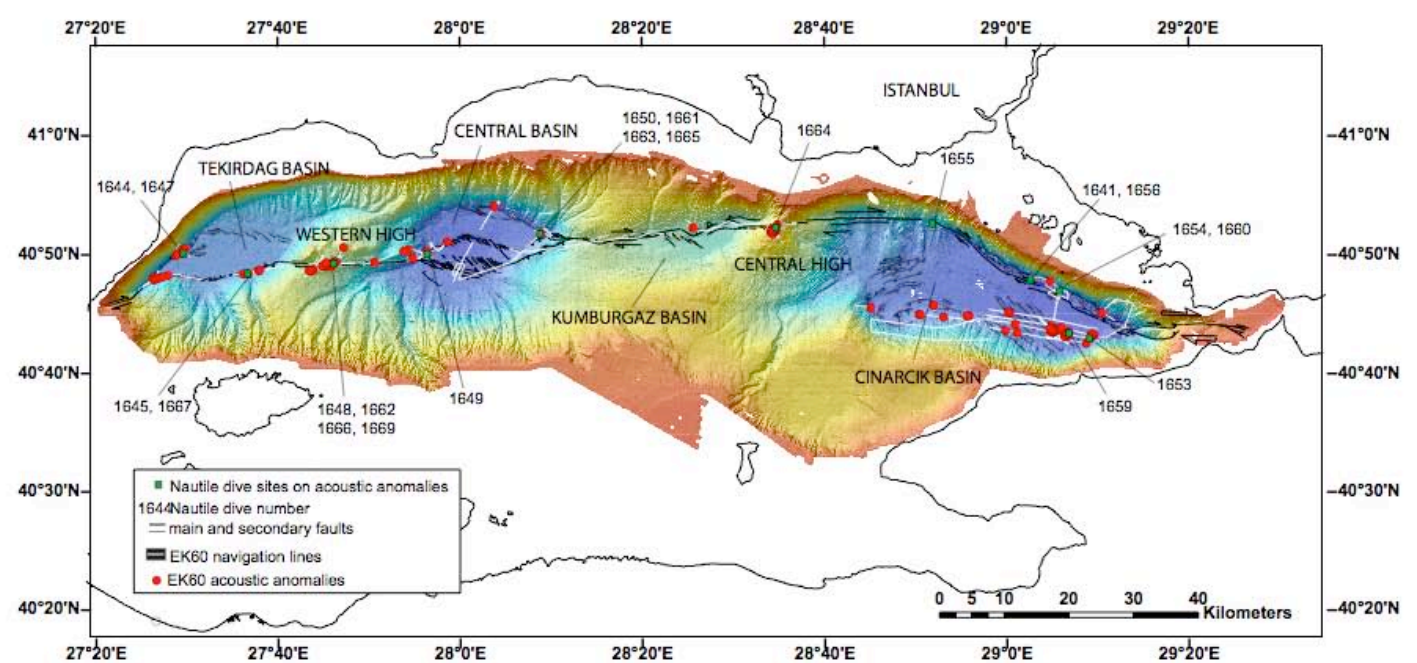

FIGURE 2b 


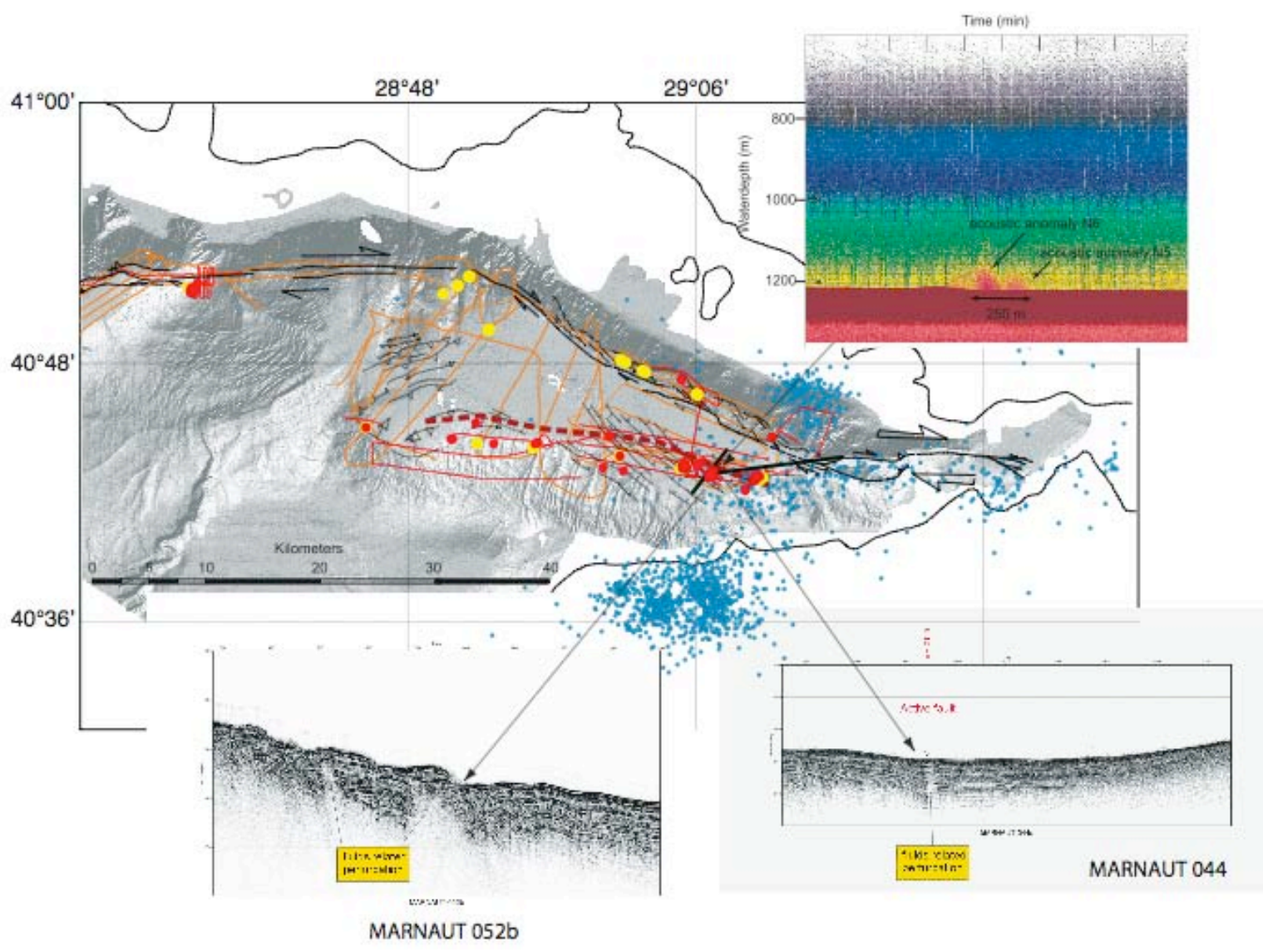

FIGURE 3 


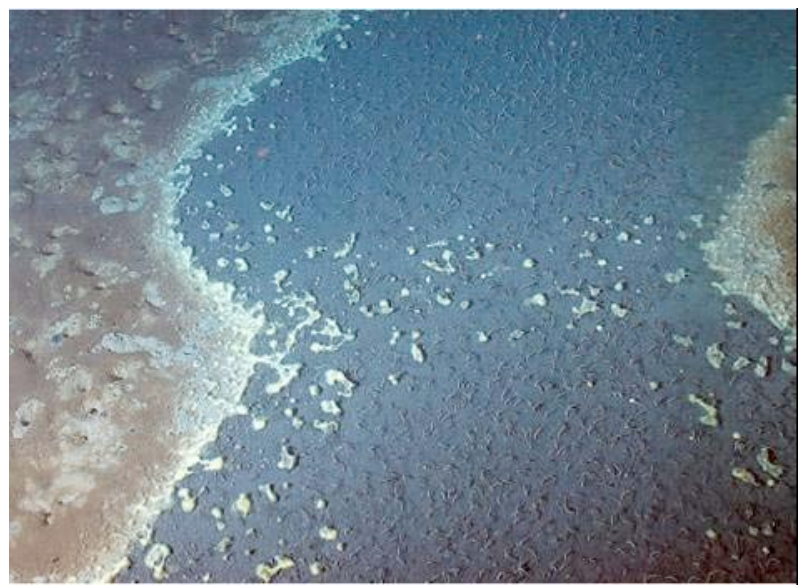

FIGURE 4a

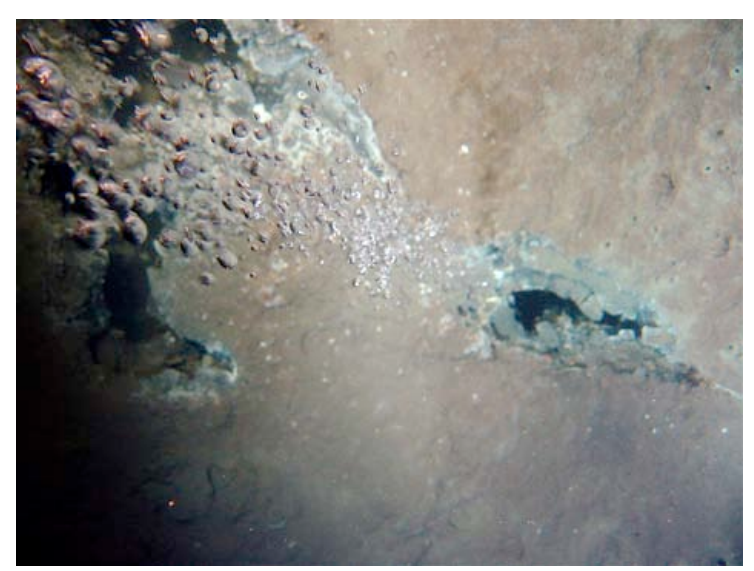

FIGURE4b 